\title{
Personal business ethics in global business: a cross-cultural study between France and the USA
}

\section{Lam D. Nguyen}

University of Economics,

Ho Chi Minh City,

59C Nguyễn Đình Chiểu, Phường 6, Quận 3,

Thành phố Hồ Chí Minh, Vietnam

Email: lam.nguyen@isb.edu.vn

and

Bloomsburg University of Pennsylvania,

400 E 2nd St, Bloomsburg, PA 17815, USA

Email: lnguyen@bloomu.edu

\section{Jet Mboga* and Wai Kwan Lau}

Bloomsburg University of Pennsylvania,

400 E 2nd St, Bloomsburg, PA 17815, USA

Email: jmboga@bloomu.edu

Email:wlau@bloomu.edu

*Corresponding author

\section{Loan N.T. Pham}

Pennsylvania State University,

Burrowes Street, State College PA 16801, USA

Email:1np16@psu.edu

\section{Thomas Tanner}

Bloomsburg University of Pennsylvania, 400 E 2nd St, Bloomsburg, PA 17815, USA

Email: ttanner@bloomu.edu

\begin{abstract}
This study examines the personal business ethics perceptions of students in France and in the US by using Clark and Clark's (1966) personal business ethics scores (PBES) scale. By analysing the ethical perception of 464 business students using two-way ANOVA statistical method on country, gender, business law courses, and ethics training, this study found some significant results. French students in this sample appeared to have lower PBES scores than their US counterparts. In addition, respondents' PBES scores were significantly different based on business law courses. Students who took business law courses had a higher PBES scores than those who did not. Moreover, students who had ethics training experience scored marginally higher than those who did not. Gender, however, was not a significant factor.
\end{abstract}


Keywords: business law courses; ethics training; France; gender; personal business ethics scores; PBES; the USA.

Reference to this paper should be made as follows: Nguyen, L.D., Mboga, J., Lau, W.K., Pham, L.N.T. and Tanner, T. (2022) 'Personal business ethics in global business: a cross-cultural study between France and the USA', Int. $J$. Business Governance and Ethics, Vol. 16, No. 1, pp.1-15.

Biographical notes: Lam D. Nguyen is a Professor and Chair of the Department of Management and International Business at Bloomsburg University of Pennsylvania. He is a Research Fellow at the University of Economics, Ho Chi Minh City in Vietnam. He has been on the editorial board and served as a Guest Editor for refereed journals such as International Journal of Public Administration. He has served as a Visiting Professor in Thailand and Vietnam. He has published numerous articles in refereed journals such as Leadership \& Organizational Development Journal and others.

Jet Mboga is an Assistant Professor of Management and International Business at Bloomsburg University. Her research interests include international business: Sub-Saharan Africa, organisational leadership impact on business and society; organisational behaviour, ethical decision-making, cross-cultural management, and corporate governance (strategy). Her education is credited with a $\mathrm{PhD}$ from the University of Bolton - UK and Doctor of Business from the Administration Walden University - Minneapolis, MN.

Wai Kwan (Elaine) Lau is an Associate Professor of Management and International Business at Bloomsburg University. She received her $\mathrm{PhD}$ from the University of North Texas. Her research has been published in multiple high-quality refereed journals such as International Journal of Conflict Management, Asia Pacific Business Review, and Leadership \& Organizational Development Journal. Her research interests include leadership, personality, organizational learning, and related cross-culture studies.

Loan N.T. Pham is a $\mathrm{PhD}$ student in the Workforce Education and Development Program at Pennsylvania State University. She was an Adjunct Professor in the Zeigler College of Business at Bloomsburg University of Pennsylvania and Lecturer of Marketing and Management at Banking University of Ho Chi Minh City in Vietnam. Her research has been published in multiple high-quality refereed journals including Leadership and Organization Development, Journal of Asia Business Studies, and others. Her areas of research are leadership, HRM, business ethics and consumer ethics, entrepreneurship in cross cultural setting and international marketing.

Thomas Tanner is an Associate Professor of Marketing at the Zeigler College of Business at Bloomsburg University of Pennsylvania. He has 25+ years of experience as both academic faculty and agency practitioner. He has been successful in working with companies from all industries helping to provide strategic guidance and also has considerable agency experience with several of the largest brands. His research has been published in multiple high-quality refereed journals including International Journal of Human Resources: Development and Management and International Journal of Business and Globalization. His areas of interest are leadership, cultural diversity, marketing management, and international marketing. 


\section{Introduction}

In a world where business is now defined in terms of globalisation, there continues to be an increasing importance of understanding cultural implications for organisational decisions. Globalisation defines the business world today; yet, it also leads to many types of misunderstandings regarding ethics, motives, and trust (Curtis et al., 2017). As more and more businesses tend to operate on vast international scales, the differences in cultural behaviour and mentality can have unprecedented results in the marketplace. The concern of unethical practices and behaviour continues to be an area of discussion for organisations as the mindset of businesses vary from country to country.

There have been considerable number of major scandals that have impacted the international landscape in nearly all facets of an organisation. From Enron to WorldCom, Samsung to Caterpillar, and Wells Fargo to Deutsch Bank, these companies have all shared the unfortunate realities of unethical business actions and organisational decision making on a global scale. Burton (2012) stipulated that an ongoing challenge to conducting successful global business is understanding people's culture and motivation. Similarly, differences in ethical intentions can be explained by different inputs into the ethical decision-making process resulting in different outcomes (Hendy and Montargot, 2019; Rest, 1979; Smith, 2018). The increasing need to understand the underlying reasons for unethical behaviours and possible preventive measures has become tremendously imperative.

More importantly, the issue of business ethics has been and continues to be of growing interest to academics, practitioners, and governmental agencies (Craft, 2010; Gift et al., 2013; Nguyen et al., 2016b). Cova et al. (2018) reinforced the staggering reality that even from the beginning of this millennium, several scandals and other examples of unethical behaviour have affected the business profession all over the world. This is an ongoing dilemma that the business community will nevertheless have to face on an ongoing basis. The results of these unethical decisions span across disciplines and international borders alike. Poor ethical choices have impacted "investors, accountants, marketers, analysts, technology, and even consumers in attempts to gain leverage in the marketplace" (Kertechian, 2018; Thorpe and Roper, 2019). Furthermore, cross-cultural studies are critical to understand the differences in the perceptions of business ethics in different countries (Bergerac et al., 2011; Forganni and Reed, 2019; Nguyen et al., 2014).

In respect to this research, the authors have chosen to compare business student's ethical maturity between France and the USA for various reasons. One of the more underlying reasons stems from the fact that "France is in a similar socioeconomic position to the U.S., yet has historically different relations, beliefs about personal responsibility, and cultural values" (Fysh and Wolfreys, 2003; Khosla et al., 2018; The World Bank, 2014). This provides a great comparison from countries with relatively similar economic perspectives so the focus can be on the differences in personal decisions and cultural values. These similarities shared in conjunction with the differences in cultural heritage and personal responsibility could very well influence people's attitude toward business ethics.

Furthermore, there has also been very limited research interpreting the ethical maturity between these two countries. Previous research identifying the cross-cultural importance between countries have already been established (Bergerac et al., 2011; Curtis et al., 2017; Gift et al., 2013; Khosla et al., 2018; Nguyen and Pham, 2015). However, the analysis between France and the US has had very little comparison. This 
provides a unique opportunity to enhance findings from earlier research to strengthen the importance of ethics in business on an international level.

\section{Literature review}

\subsection{Corruption perception index - the US and France}

There are many issues that could impact the ethical decision processes by individuals as well as organisations. Within this perspective, corruption can be a fundamental construct that mitigates how ethical decisions, or unethical decisions, will be made and handled. Corruption can be defined and observed in many aspects, from legal, sociological, to philosophical (Smith, 2018). The concerns with corruption are not new concerns, but one that tends to evolve over time as political and economic stability within nations get more and more effected.

There are several instances that create a need for further evaluation into this world of corruption and unethical behaviours within nations. For instance, in France, corruption tends to occur at the highest levels of government (Cova et al., 2018). The petty corruption that most nations face is usually overlooked and becomes secondary to the immense scandals that impact both government and economy. From the French political scandals involving former president Jacque Chirac who was found guilty of manipulating election results and bribery to the energy mega-corporation Alstom in 2007 that made illegal payments of nearly $\$ 200$ million US dollars to secure contracts in neighbouring countries, these corruption cases have implications that trickle down to the general population (Hendy and Montargot, 2019). A few other corruption cases and unethical decisions that have made headlines over the years include the former president of the financial commission Jerome Cahuzac who was found guilty of embezzling national funds to an offshore account in Switzerland to former presidential candidate Francoise Fillon who was found guilty of transferring taxpayers' money to his wife's account for nearly $\$ 900,000$ US dollars.

The US is not immune to these types of corruption scandals as well. As mentioned earlier, the most notable cases stem from Enron, Caterpillar, to WorldCom. These scandals impacted the US economy since it created distrust and apprehension in the minds of consumer and consumer spending. A few additional scandals that undoubtedly impacted a nation include the Bernie Madoff scheme that attributed to the financial crisis in the economy in 2008 to the 'Panama papers' in 2016 that released never before seen confidential documents of the wealthy who use tax havens to hide their wealth. The list continues to go on, however, the main implications for these types of corruption scandals create a negative perception in the marketplace that can cause significant swings in consumer purchase and sales that ultimately lead to economic instability (Gift et al., 2013; Schoen, 2017).

As indicated in Table 1, the corruption perception index (CPI) of France and the US (2012-2018) issued by Transparency International are highlighted. From this chart, a comparison and distinct perspective between France and the US can be seen. France and the US are very similar in their respective positions surrounding corruption. The US experiences a big drop from 75 in 2017 to 71 in 2018 while France experiences a slight increase from 70 in 2002 and 72 in 2018. The higher CPI score (except for 2018) indicates that the US is thought to have less corruption issues than France. However, it is 
imperative to understand that a big part of this could be due to the perception of the political and presidential environment in the US today (Transparency International, 2018).

Table 1 CPI of France and the US (2012-2018)

\begin{tabular}{lccccccc}
\hline \multirow{2}{*}{ Country } & $C P I$ & $C P I$ & $C P I$ & $C P I$ & $C P I$ & $C P I$ & $C P I$ \\
& 2018 & 2017 & 2016 & 2015 & 2014 & 2013 & 2012 \\
\hline USA & 71 & 75 & 74 & 76 & 74 & 73 & 73 \\
France & 72 & 70 & 69 & 70 & 69 & 71 & 71 \\
\hline
\end{tabular}

Source: Transparency International $(2017,2018)$

\subsection{Cross-cultural business ethics}

Cultural factors that entail national identity, law, religion, values and customs, respect for individuality, and rights of property are part of the aspects influencing individual's ethical decisions in business (Crane et al., 2019; Pekerti and Arli, 2017). In a cross-cultural comparison of Vietnam and US students, Nguyen and Pham (2015) find US students to have higher ethical attitudes than Vietnam students. Khan et al. (2015) confirm that university students' attitudes towards business ethics were low among Saudi Arabia students and high among Pakistan students. In a study of how ethical beliefs are framed when students live in a new cultural context, Jaffe et al. (2018) reveal that levels of ethical beliefs vary based on the student's origin: the Israel native students select the most ethical approaches; the Ukraine native students pick the least ethical approach; and the Ukraine immigrants to Israel have combined ethical beliefs from native-Ukraine and host-Israel that affected their decision making regardless of them living in a different business environment. Gelbrich et al. (2016) utilise the GLOBE dimensions and controls to examine culture on context to a country's wealth; using data from 54 countries the results confirm that cultural discrepancies and the country's wealth drive corruption with poor nations being more corrupt than rich nations. van Hoorn (2019) study on the importance of cross-national values among 32 countries documents the importance of understanding the diverse cultural values among nations, younger, and older managers; they emphasise that there exist diverse shifts that should be converged to attain organisational goals while addressing birth cohorts and cross-border cultures. The effects of moral integrity and consumer relationship among China and US were assessed by Li et al. (2018). The results convey that integrity had a significant impact on consumer trust and relationship commitment both directly and indirectly among US responders while integrity had an indirect effect on relationship commitment among the Chinese responders. The results emphasise that when there is lack of integrity the trust erodes among US but among there is no direct correlation among the Chinese consumers trust. With that in mind, the authors propose the following hypothesis:

H1 There is a difference in the personal business ethics scores (PBES) scores between business students in France and in the US.

\subsection{Gender effects on business ethics}

Research on the effects of gender and business ethics supports a variance that females are cautious responders and possess higher ethical standards than males (Meyers-Levy and 
Loken, 2015; Suar and Gochhayat, 2016; Wang and Calvano, 2015). Wang and Calvano (2015) analyse students in the East Coast of the US and outline that gender played a role in ethics with women taking more caution in business situation than males. In addition, Nguyen et al. (2016b) find that female students were more ethical than males across the US and Vietnam. Dwita et al. (2018) report that Indonesian female students were termed as 'holier than thou' which signifies that females observe societal norms and are more ethical than male students. In assessing and analysing the effects of CEO gender on accounting conservatism, Ho et al. (2015) find an optimistic correlation that female CEOs were more ethical than their male counterparts, adopted stringent ethical stance, recognised negative news, and reported conservative earnings. Chen et al. (2016) study managers from 27 nations and find that unethical conduct that includes tax evasion and bribery were less common among females but more pronounced among males who were ready to justify their business-related unethical actions. Tlaiss (2015) studies Islamic women entrepreneurs from United Arab Emirates, Lebanon, Kuwait, and Oman and identifies that gender played a role in business ethics with women being ethical and upholding Islamic ethics of honesty, truth, and justice in running their business. With that being said, the authors propose the following hypothesis:

$\mathrm{H} 2$ There is a difference in the PBES scores between male and business students.

\subsection{Business law course and ethics training effects on business ethics}

Quick changes, competition, new generation needs, and consumer protection around the globe have sparked a need for managers to be equipped with procedural ways to handle cross-cultural ethical dilemmas (Chen, 2017; Liu and Xu, 2018; Salehar, 2015). Prevailing research designates that development and adoption of effective training programs within organisations has a direct relationship to fewer unethical behaviours within the workplace and successful managers and leaders in our globalised world (Kaptein, 2015; Ruiz et al., 2015; Weber, 2015). In a study comparing ethical perceptions of Vietnam and US students taking business law courses, ethics training, and workshops, Nguyen et al. (2016b) reveal that culture specific ethics education increases the student's level of ethics awareness and has a positive impact on their moral development. Gabel (2005) examines the importance of studying business law courses and emphasises that students who have not taken business law courses lack stronger moral compass than students taking business law courses who are able to facilitate creativity, growth, and competitive advantage as they partake in ethical managerial decision making. Prentice (2001) confirms that accounting students who possess strong legal background and are legally educated will excel in their respective roles and take ethical measures than those who are legally naïve. Law course analysis conducted by Brown (2013) confirms that students who took business law courses are equipped with legal principles that cultivate developmental thinking skills on how to detect and address possible legal concerns and are valuable to their employers than students who never took business law courses as they possess ambiguous ideas on the law and how to handle concerns as they arise. In an examination of Australian students taking business ethics course, Neesham and $\mathrm{Gu}$ (2015) disclose that moral identified and focused business ethics teaching increases intensity of moral judgement among students. A study conducted by Ermasova et al. (2017) find a substantial difference in ethical perception between Russian business students who had ethics education and those who did not. They believe that ethical 
students who enter the workforce promote ethical climate within the workplace. Martinov-Bennie and Mladenovic (2015) measure student's ethical decision and sensitivity in business in Australia and conclude that having a framework for ethical decision alone increased student's ethical decision while the integration of ethics component along with that framework contributed to students who were ethically sensitive in their ethical decision-making process. Mladenovic et al. (2019) reveal that the use of comprehensive and theoretical ethics course content and taking a holistic approach to ethics education contributed to an effective ethics education among students who developed an increase on ethics in social, government, and business context. To measure the effectiveness of business education, Wang and Calvano (2015) analyse students in the US and their results confirm that ethics training contributed to students making ethical decisions when faced with a dilemma in the workplace. Remišová et al. (2019) investigate Central and Eastern Europe - Slovakia managers and find that continuous ethics training programs that encompass collective discussions, counselling on how to resolve ethical issues, and compliance group norms helped managers shape and foster ethical behaviours among managers. They found that effective ethics programs within organisations reinforce ethical competencies learned during university level and boost trust among managers to act ethically. Warren et al. (2014) examine bank employees before and after an implementation of an ethics and compliance training program and report a reduction of unethical behaviours on the second year of the study showing evidence that effective training improves ethical standards. With that being said, the authors propose the following hypotheses:

H3 Business law course makes a difference in the PBES scores of business students.

H4 Ethics training makes a difference in the PBES scores of business students.

\section{Methodology}

\subsection{Subjects}

This paper investigates the ethical perception of business students in France and the US. The key interest is to find out if there is a difference in these students' ethical perception. The study also takes a closer look into the difference (if any) by analysing several variables including gender, business law course, and ethics training. The authors used the data that were published in previous studies (Nguyen et al., 2014; Sarkessian and Nguyen, 2018). The French sample included students who mainly came from a business school in Nancy while the US sample included students who mostly studied at a business school in Florida. A total sample of 464 students, of which 178 were from France and 286 were from the US, were used for analysis.

\subsection{Instrument scale}

The scale was PBES (Clark and Clark, 1966). It consists of 11 mini situations regarding ethical issues with a decision in each situation. Students were asked to provide their opinions regarding the decision in these situations by rating the decisions on a scale with a possible lowest total score of 11 and a highest total score of 55 (1 to 5 for each situation respectively), as shown in Table 2 . The higher the score, the higher the ethical perception. 
Table 2 PBES scores

\begin{tabular}{lc}
\hline Scores & Descriptions \\
\hline $50-55$ & Very high range \\
$44-49$ & High range \\
$38-43$ & Moderately high range \\
$32-37$ & Moderately low range \\
$26-31$ & Low range \\
$11-25$ & Very low range \\
\hline
\end{tabular}

SPSS 24.0 was used to analyse the data and test hypotheses. As seen in Table 3. The French sample was smaller $(38.4 \%)$ than the US sample $(61.6 \%)$. There were more female respondents $(55.4 \%)$ than male respondents $(44.6 \%)$. However, there were more males $(59 \%)$ within the French sample while there were more females within the US sample $(64.3 \%)$. In terms of age, the 17-25 age group was dominant in the French sample $(97.2 \%)$, which was understandable since most of the respondents were undergraduate students. Meanwhile, the age groups were more spread out in the US sample with more than two-third $(73.5 \%)$ were from 17 to 35 years of age. Especially, there were 71 respondents who were 36 years of age and above $(26.5 \%)$ in the US sample while there were only three respondents in the French sample who were in the same age group. This was because there were more non-traditional students in the US sample.

Table 3 Sample statistics $(\mathrm{N}=464)$

\begin{tabular}{cccc}
\hline & \multicolumn{2}{c}{ Country } & \multirow{2}{*}{ Total } \\
\cline { 2 - 3 } & $n=286(61.6 \%)$ & $\begin{array}{c}\text { France } \\
n=178(38.4 \%)\end{array}$ & \\
\hline Gender & & & $207(44.6 \%)$ \\
Male & $102(35.7 \%)$ & $105(59.0 \%)$ & $257(55.4 \%)$ \\
Female & $184(64.3 \%)$ & $73(41.0 \%)$ & \\
Age & & & $293(63.2 \%)$ \\
$17-25$ & $120(42.0 \%)$ & $173(97.2 \%)$ & $92(19.8 \%)$ \\
$26-35$ & $90(31.5 \%)$ & $2(1.1 \%)$ & $47(10.1 \%)$ \\
$36-45$ & $45(15.7 \%)$ & $2(1.1 \%)$ & $29(6.3 \%)$ \\
$46-55$ & $28(9.8 \%)$ & $1(0.6 \%)$ & $3(0.6 \%)$ \\
46 and above & $3(1.0 \%)$ & $0(0.0 \%)$ & \\
\hline
\end{tabular}

\subsection{Reliability}

Table 4 indicates a satisfactory reliability of the scale with Cronbach's $\alpha(0.953)$ and Cronbach's $\alpha$ if item deleted were greater than 0.9 (Nunnally, 1978). 
Table 4 Reliability statistics

\begin{tabular}{|c|c|c|c|c|c|}
\hline \multicolumn{2}{|c|}{ Cronbach's $\alpha$} & \multicolumn{3}{|c|}{ Cronbach's $\alpha$ based on standardised items } & \multirow{2}{*}{$\frac{\text { No. of items }}{11}$} \\
\hline & 53 & & 0.953 & & \\
\hline Item & $\begin{array}{l}\text { Scale mean } \\
\text { if item } \\
\text { deleted }\end{array}$ & $\begin{array}{l}\text { Scale variance } \\
\text { if item deleted }\end{array}$ & $\begin{array}{l}\text { Corrected } \\
\text { item-total } \\
\text { correlation }\end{array}$ & $\begin{array}{l}\text { Squared } \\
\text { multiple } \\
\text { correlation }\end{array}$ & $\begin{array}{l}\text { Cronbach's } \\
\text { alpha if item } \\
\text { deleted }\end{array}$ \\
\hline PBES 1 & 32.77 & 122.979 & 0.668 & 0.476 & 0.953 \\
\hline PBES 2 & 32.70 & 119.726 & 0.733 & 0.569 & 0.950 \\
\hline PBES 3 & 32.69 & 118.804 & 0.770 & 0.612 & 0.949 \\
\hline PBES 4 & 32.53 & 112.332 & 0.864 & 0.773 & 0.946 \\
\hline PBES 5 & 32.68 & 117.496 & 0.829 & 0.695 & 0.947 \\
\hline PBES 6 & 32.48 & 112.566 & 0.871 & 0.779 & 0.945 \\
\hline PBES 7 & 32.73 & 118.704 & 0.769 & 0.623 & 0.949 \\
\hline PBES 8 & 32.67 & 118.563 & 0.796 & 0.652 & 0.948 \\
\hline PBES 9 & 32.65 & 118.907 & 0.804 & 0.654 & 0.948 \\
\hline PBES 10 & 32.84 & 119.285 & 0.748 & 0.574 & 0.950 \\
\hline PBES 11 & 32.77 & 120.367 & 0.784 & 0.638 & 0.949 \\
\hline
\end{tabular}

\section{Results}

The authors tested all three hypotheses by using univariate analysis of variance (two-way ANOVA). This statistical method was appropriate since the purpose of this study was to investigate whether there is a difference on the PBES scores between business students in France and the US based on country, gender, business law course, and ethics training. It was also used to find out the interaction between these factors on the PBES scores. Table 5 showed key hypothesis testing outcomes. First, US students' mean PBES score $(\mathrm{M}=43.8)$ was in the 'high range' while French students' mean PBES score $(\mathrm{M}=23.3)$ was in the 'very low range'. The result confirmed this was a statistically significant difference $(\mathrm{F}=1,032.593, \mathrm{p}=0.000)$. Thus, Hypothesis 1 'There is a difference in the PBES scores between business students in France and in the US' was supported. French students scored lower than their US counterparts. In other words, French students have lower ethical maturity than the US students. Table 5 also indicated that the mean PBES score of male students $(M=33.2)$ was in the 'moderately low range' while the mean PBES score of female students $(\mathrm{M}=38.2)$ was in the 'moderately high range'. However, this difference was not statistically significant $(\mathrm{F}=0.326, \mathrm{p}=0.568)$. As a result, Hypothesis 2 'There is a difference in the PBES scores between male and female business students' was not supported. Moreover, Table 5 illustrated that the mean PBES score of students who took business law course $(\mathrm{M}=36.2)$ and that of students who did not $(\mathrm{M}=34.8)$ were in the 'moderately low range'. The result confirmed this was a statistically significant difference $(\mathrm{F}=6.610, \mathrm{p}=0.010)$. Hypothesis 3 'Business law course makes a difference in the PBES scores of business students' was supported. Students who took business law courses appeared to have higher ethical perception than those who did not take such course. As presented in Table 5, the mean PBES score of students who experienced ethics training $(\mathrm{M}=42.0)$ was in the 'moderately high range' 
while that of students who did not have such experience $(\mathrm{M}=31.0)$ was in the 'low range'. The result confirmed this was a marginally significant difference $(\mathrm{F}=3.354$, $\mathrm{p}=0.068<0.01$ ). Thus, Hypothesis 4 'Ethics training makes a difference in the PBES scores of business students' was partially supported at 0.1 level. Business students who experienced ethics training appeared to have higher ethical perception than those who did not have such experience.

Table 5 Hypothesis testing results $(\mathrm{N}=464)$

\begin{tabular}{|c|c|c|c|c|c|c|c|}
\hline \multicolumn{2}{|c|}{ Country } & \multicolumn{2}{|c|}{ Gender } & \multicolumn{2}{|c|}{$\begin{array}{l}\text { Business law } \\
\text { course }\end{array}$} & \multicolumn{2}{|c|}{ Ethics training } \\
\hline US & France & Male & Female & Yes & No & Yes & No \\
\hline$M=43.8$ & $M=23.3$ & $\mathrm{M}=33.2$ & $\mathrm{M}=38.2$ & $M=36.2$ & $M=34.8$ & $M=42.0$ & $\mathrm{M}=31.0$ \\
\hline \multicolumn{2}{|c|}{$\begin{array}{c}\qquad \mathrm{F}=1032.593 \\
\mathrm{p}=0.000 \\
\mathrm{R}^{2}=0.706 \\
\text { Adjusted } \mathrm{R}^{2}=0.704\end{array}$} & \multicolumn{2}{|c|}{$\begin{array}{c}\mathrm{F}=0.326 \\
\mathrm{p}=0.568 \\
\mathrm{R}^{2}=0.706 \\
\text { Adjusted } \mathrm{R}^{2}= \\
0.704\end{array}$} & \multicolumn{2}{|c|}{$\begin{array}{c}\mathrm{F}=6.610 \\
\mathrm{p}=0.010 \\
\mathrm{R}^{2}=0.713 \\
\text { Adjusted } \mathrm{R}^{2}= \\
0.712\end{array}$} & \multicolumn{2}{|c|}{$\begin{array}{c}\mathrm{F}=3.354 \\
\mathrm{p}=0.068 \\
\mathrm{R}^{2}=0.712 \\
\text { Adjusted } \mathrm{R}^{2}= \\
0.711\end{array}$} \\
\hline
\end{tabular}

Notes: Computed using alpha $=0.05$; dependent variable: PBES.

Table 6 demonstrated the interactions between country and gender, business law course, and ethics trainings on the PBES scores. The interaction between country and gender was not significant $(\mathrm{F}=0.788, \mathrm{p}=0.375)$. A good way to explain the meaning of an insignificant interaction between variables is to check the observed power value (Nguyen et al., 2016a). Table 6 showed that there would be only $14.4 \%$ chance that the effect of country on the difference of mean PBES scores is influenced by gender. However, the interaction between country and business law course was partially significant ( $F=0.3 .444, p=0.064<0.10)$. In other words, there would be $45.7 \%$ chance that the effect of country on the difference of mean PBES scores is influenced by business law course. Similarly, the interaction between country and ethics training was partially significant $(\mathrm{F}=0.3 .068, \mathrm{p}=0.081<0.10)$. Thus, there would be $41.6 \%$ chance that the effect of country on the difference of mean PBES scores is influenced by ethics training.

Table 6 Tests of between-subjects effects $(\mathrm{N}=464)$

\begin{tabular}{lccccc}
\hline Source & $F$ & Sig. & $\begin{array}{c}\text { Partial eta } \\
\text { squared }\end{array}$ & $\begin{array}{c}\text { Non-cent. } \\
\text { parameter }\end{array}$ & $\begin{array}{c}\text { Observed } \\
\text { power }\end{array}$ \\
\hline Country * Gender & 0.788 & 0.375 & 0.002 & 0.788 & 0.144 \\
Country * Business law course & 3.444 & 0.064 & 0.007 & 3.444 & 0.457 \\
Country * Ethics training & 3.068 & 0.081 & 0.007 & 3.068 & 0.416 \\
\hline
\end{tabular}

Note: ${ }^{\mathrm{b}}$ Computed using alpha $=.05$

\section{Discussion and managerial implications}

This paper investigated the personal business ethics perception of business students in France and in the US based on gender, business law course and ethics training. First, the statistical results confirm that there is a significant difference in the personal business ethics perception between business students in France and in the US. More particularly, 
French students seem to have lower ethical maturity than the US students since their PBES scores fell in the very low ethical range while the US students' PBES scores fell in the high ethical range. This finding provides further empirical evidence to support previous studies in confirming that ethical perceptions of people from different countries are different (Bergerac et al., 2011; Nguyen and Pham, 2015; Preble and Reichel, 1988; Shields et al., 2013; Sims and Gegez, 2004; Vitell et al., 1993). As for managerial implications, since the target respondents are mainly business students who are currently in or will be joining the global workforce, the authors strongly suggest managers, especially those who may handle employees who come from France and the US, understand and pay more attention to the difference in their business ethics perceptions. Managers and leaders need to tailor their leadership styles and develop business practices and ethics programs accordingly. The notion of 'one size fits all' should not be applied when leaders and managers create and implement ethics programs for their global organisations across cultures.

Second, the statistical results confirm that there is a marginally significant difference in the personal business ethics perception between business students who took business law course and those who did not. Business students who took business law course appeared to have higher ethical perception than those who did not take such courses. This supports Brown (2013) and Prentice's (2001) suggestion that business law courses can help business students act ethically, which in turn confirms the importance of legal education in the business discipline curriculums. The authors highly suggest an inclusion of business law courses in the business discipline curriculums at higher educational institutions, particularly in France and the US.

Third, the statistical results confirm that there is a marginally significant difference in the personal business ethics perception between business students who experienced ethics training and those who did not. Ethics training seemed to be a significant factor in the ethical score difference. Business students appeared to have higher level of awareness of ethical issues and responded more positively to these issues. This finding supports previous studies (e.g., Nguyen et al., 2016a, 2016b; Remišová et al., 2019; Wang and Calvano, 2015; Warren et al., 2014) in providing empirical evidence to reaffirm the importance of ethics trainings in individual's ethical maturity. The authors highly suggest that business leaders and managers offer and create incentives for their employees to actively and frequently participate in ethics training. This will help educate and prepare the workforce for dealing with complex ethical issues more effectively.

\section{Limitations and future research}

As many other quantitative studies, this study recognises some limitations. First, data used in this study had been collected previously for other studies by using convenient samples. The respondents were mostly from a specific area of the country, i.e., Nancy in France and Florida in the US, and thus were not the perfect representation of the whole populations of these two countries. Second, due to the small sample size, any cross-cultural generalisation of the findings should be avoided. Third, the survey instrument was about the perception/opinion of respondents. Consequently, it did not examine the actual behaviour of respondents, which could result in personal bias. Finally, in this study, the intention of the authors was to examine only the differences on ethical perceptions based on country, gender, business law course, and ethics training. No causal 
conclusions should be attempted from the results. The authors suggest some possibilities for future research. First, longitudinal studies can be conducted to examine how changes in demographic variables and other economic factors can affect individual's ethical perception. Second, the impact of cultural dimensions, e.g., power distance, individualism/collectivism, can be examined. Third, similar studies can be extended to examine ethical perception of different generations given the nature of the diverse workforce in today's global business environment. Finally, similar comparative studies that include countries from different continents are highly encouraged.

\section{References}

Bergerac, D., Furrer, O. and Reynaud, E. (2011) 'Management students' attitudes toward business ethics: a comparison between France and Romania', Journal of Business Ethics, Vol. 98, No. 1, pp.391-406, DOI: 10.1007/s10551-010-0555-5.

Brown, E.A. (2013) 'The role of law in business education', in Hardy, G.M. and Everett, D.L. (Eds.): Shaping the Future of Business Education: Relevance, Rigor, and Life Preparation, pp.142-152, Palgrave McMillan, London, https://doi.org/10.1057/9781137033383_12.

Burton, F. (2012) 'Discussion of: a cross-cultural study of the influence of country of origin, justice, power distance, and gender on ethical decision making', Journal of International Accounting Research, Vol. 11, No. 1, pp.35-44, DOI: 10.2308/jiar-10222.

Chen, C.W., Velasquez Tuliao, K., Cullen, J.B. and Chang, Y.Y. (2016) 'Does gender influence managers' ethics? A cross-cultural analysis', Business Ethics: A European Review, Vol. 25, No. 4, pp.345-362, DOI: https://doi.org/10.1111/beer.12122.

Chen, Z.J. (2017) 'Cross-cultural adaptation challenges to management innovation in multinational business context: theoretical model and practices', in Erbe, N.D. (Ed.): Approaches to Managing Organizational Diversity and Innovation, pp.187-211, IGI Global, Hershey, PA, DOI: 10.4018/978-1-4666-6006-9.

Clark, J.W. and Clark, S.J. (1966) Religion and Moral Standards of American Businessmen, Southwestern Publishing Co., Cincinnati, $\mathrm{OH}$.

Cova, B., Gaglio, G., Weber, J. and Chanial, P. (2018) 'Organizational sensemaking of non-ethical consumer behavior: case study of French mutual insurance company', Journal of Business Ethics, Vol. 148, No. 1, pp.783-799, DOI: https://doi.org/10.1007/s10551-016-3102-1.

Craft, J. (2010) 'Making the case for ongoing and interactive organizational ethics training', Human Resource Development International, Vol. 13, No. 5, pp.599-606, DOI: https://doi.org/10.1080/13678868.2010.520484.

Crane, A., Matten, D., Glozer, S. and Spence, L. (2019) Business Ethics: Managing Corporate Citizenship and Sustainability in the Age of Globalization, Oxford University Press, London, UK.

Curtis, M., Vinson, J., Conover, T., Lucianett, L. and Battista, V. (2017) 'National culture an ethical judgment: a social contract approach to the contrast of ethical decision making by accounting professionals and students from the U.S. and Italy', Journal of International Accounting Research, Vol. 16, No. 2, pp.103-120, DOI: 10.2308/jiar-51824.

Dwita, S., Helmy, H. and Chreisviyanny, C. (2018) 'The influence of gender and personality on 'holier-than-thou' perception bias among Minangkabau accountants', International Journal of Economics and Management, Vol. 12, No. S1, pp.1-15.

Ermasova, N., Wagner, S. and Nguyen, L.D. (2017) 'The impact of education, diversity, professional development and age on personal business ethics of business students in Russia', Journal of Management Development, Vol. 36, No. 3, pp.410-426, https://doi.org/10.1108/ JMD-08-2016-0153. 
Forganni, A. and Reed, H. (2019) 'Circumvention of trade defence measures and business ethics', Journal of Business Ethics, Vol. 155, No. 1, pp.29-40, DOI: https://doi.org/10.1007/s10551017-3536-0.

Fysh, P. and Wolfreys, J. (2003) The Politics of Racism in France, Palgrave MacMillan, New York, NY.

Gabel, J.T.A. (2005) 'Editor's corner: law and ethics in the business school', American Business Law Journal, Vol. 42, Nos. 1-6, pp.2-5, 6, https://doi.org/10.1111/j.17441714.2005.04206001.x.

Gelbrich, K., Stedham, Y. and Gäthke, D. (2016) 'Cultural discrepancy and national corruption: Investigating the difference between cultural values and practices and its relationship to corrupt behavior', Business Ethics Quarterly, Vol. 26, No. 2, pp.201-225, DOI: http://dx.doi.org/10.1017/beq.2016.29.

Gift, M., Gift, P. and Zheng, Q. (2013) 'Cross-cultural perceptions of business ethics: evidence from the United States and China', Journal of Business Ethics, Vol. 114, No. 1, pp.633-642, DOI: 10.1007/s10551-013-1709-z.

Hendy, N. and Montargot, N. (2019) 'Understanding academic dishonesty among business school students in France using the theory of planned behavior', International Journal of Management Education, Vol. 17, No. 1, pp.85-93, DOI: https://doi.org/10.1016/ j.ijme.2018.12.003.

Ho, S.S.M., Li, A.Y., Tam, K. and Zhang, F. (2015) 'CEO gender, ethical leadership, and accounting conservatism', Journal of Business Ethics, Vol. 127, No. 2, pp.351-370, DOI: http://dx.doi.org/10.1007/s10551-013-2044-0.

Jaffe, E.D., Kushnirovich, N. and Tsimerman, A. (2018) 'The impact of acculturation on immigrants' business ethics attitudes', Journal of Business Ethics, Vol. 147, No. 4, pp.821-834, DOI: http://dx.doi.org/10.1007/s10551-017-3597-0; Journal of Business Ethics, Vol. 155, No. 1, pp.29-40, DOI 1:0.1007/s10551-017-3536-0.

Kaptein, M. (2015) 'The effectiveness of ethics programs: the role of scope, composition, and sequence', Journal of Business Ethics, Vol. 132, No. 2, pp.415-431, DOI: http://dx.doi.org/ 10.1007/s10551-014-2296-3.

Kertechian, S. (2018) 'Conscientiousness as a key to success for academic achievement among French university students enrolled in management studies', International Journal of Management in Education, Vol. 16, No. 1, pp.154-165, DOI: https://oi.org/10.1016/ j.ijme.2018.02.003.

Khan, K., Gul, A. and Abdul Salam, Z. (2015) 'University students' Islāmic work ethics and their attitude towards business ethics: evidence from Asia', Journal of Islamic Business and Management, Vol. 219, No. 3425, pp.1-21, DOI: 10.12816/0027404.

Khosla, N., Perry, S., Moss-Racusin, C., Burke, S. and Dovido, J. (2018) 'A comparison of clinicians' racial biases in the United States and France', Social Science and Medicine, Vol. 206, No. 1, pp.31-37, DOI: https://doi.org/10.1016/j.socscimed.2018.03.044.

Li, F., Zhang, S. and Yang, X. (2018) 'Moral integrity and relationship commitment: an empirical examination in a cross-cultural setting', Journal of Business Ethics, Vol. 151, No. 3, pp.785-798, DOI: http://dx.doi.org/10.1007/s10551-016-3246-z.

Liu, J. and Xu, Y. (2018) How to Manage Conflicts: An Exploratory Study of Managers' Conflict Management Styles in Cross-cultural Workplace through the Lens of Cultural Intelligence, Unpublished thesis, JÖNKÖPING University, Jönköping, Sweden.

Martinov-Bennie, N. and Mladenovic, R. (2015) 'Investigation of the impact of an ethical framework and an integrated ethics education on accounting students' ethical sensitivity and judgment', Journal of Business Ethics, Vol. 127, No. 1, pp.189-203, DOI: http://dx.doi.org/ 10.1007/s10551-013-2007-5.

Meyers-Levy, J. and Loken, B. (2015) 'Revisiting gender differences: what we know and what lies ahead', Journal of Consumer Psychology, Vol. 25, No. 1, pp.129-149, DOI: https://doi.org/ 10.1016/j.jcps.2014.06.003. 
Mladenovic, R., Martinov-Bennie, N. and Bell, A. (2019) 'Business students' insights into their development of ethical decision-making', Journal of Business Ethics, Vol. 155, No. 1, pp.275-287, DOI: http://dx.doi.org/10.1007/s10551-017-3523-5.

Neesham, C. and Gu, J. (2015) 'Strengthening moral judgment: a moral identity-based leverage strategy in business ethics education', Journal of Business Ethics, Vol. 131, No. 3, pp.527-534, DOI: 10.1007/s10551-014-2483-2.

Nguyen, L. and Tran, Q. (2018) 'Working adults and personal business ethics in South East Asia: a comparative study in Thailand and Vietnam', Public Organization Review, Vol. 18, No. 1, pp.159-174, DOI: 10.1007/s11115-016-0370-2.

Nguyen, L.D. and Pham, L.N.T. (2015) 'Business students and ethics: a cross-cultural study between the U.S. and Vietnam', SAM Advanced Management Journal, Vol. 80, No. 4, pp.31-44.

Nguyen, L.D., Ermasova, N., Pham, L.N.T. and Mujtaba, B.G. (2016a) 'Cross-culture management: an examination on task, relationship and work overload stress orientations of Russians and Vietnamese', World Review of Business Research, Vol. 6, No. 1, pp.63-80, DOI: $10.1504 / \mathrm{ijscm} .2013 .057557$.

Nguyen, L.D., Tran, Q.H.M. and Pham, L.N.T. (2016b) 'Personal business ethics perceptions across cultures: an empirical investigation among business students in the US and in Vietnam', International Journal of Business Research, Vol. 16, No. 4, pp.76-87, DOI: 10.18374/IJBR16-4.7.

Nguyen, L.D., Tran, Q.H.M., Mujtaba, B.G. and Tran, C.N. (2014) 'Students and business ethics: an examination of business students at a college in Florida', Review of Business Research, Vol. 14, No. 1, pp.111-122, DOI: http://dx.doi.org/10.18374/RBR-14-1.15.

Nunnally, J.C. (1978) Psychometric Theory, McGraw-Hill, New York.

Pekerti, A.A. and Arli, D. (2017) 'Do cultural and generational cohorts matter to ideologies and consumer ethics? A comparative study of Australians, Indonesians, and Indonesian migrants in Australia', Journal of Business Ethics, Vol. 143, No. 2, pp.387-404, DOI: http://dx.doi.org/ 10.1007/s10551-015-2777-z.

Preble, R. and Reichel, A. (1998) 'Attitudes towards business ethics of future managers in the U.S. and Israel', Journal of Business Ethics, Vol. 7, No. 12, pp.941-949.

Prentice, R.A. (2001) 'The case for educating legally-aware accountants', American Business Law Journal, Vol. 38, No. 3, pp.597-631, DOI: https://doi.org/10.1111/j.1744-1714.2001. tb00297.x.

Remišová, A., Lašáková, A. and Kirchmayer, Z. (2019) 'Influence of formal ethics program components on managerial ethical behavior', Journal of Business Ethics, Vol. 160, No. 1, pp.151-166, DOI: http://dx.doi.org/10.1007/s10551-018-3832-3.

Rest, J. (1979) Development in Judging Moral Issues, University of Minnesota Press, Minneapolis, MN.

Ruiz, P., Martinez, R., Rodrigo, J. and Diaz, C. (2015) 'Level of coherence among ethics program components and its impact on ethical intent', Journal of Business Ethics, Vol. 128, No. 4, pp.725-742, DOI: http://dx.doi.org/10.1007/s10551-014-2064-4.

Salehar, M.W. (2015) Managing Cultural Diversity in a Multicultural Environment: A Qualitative Study of Middle Managers' Readiness to Manage Multicultural Teams, Doctoral dissertation, Colorado Technical University, Colorado.

Sarkessian, M. and Nguyen, L.D. (2018) 'Student's perception on business ethics: an investigation of French students based on gender, age, and education', SAM Advanced Management Journal, Vol. 82, No. 4, pp.52-60.

Schoen, E. (2017) 'The 2007-2009 financial crisis: an erosion of ethics: a case study', Journal of Business Ethics, Vol. 146, No. 1, pp.805-830, DOI: https://doi.org/10.1007/s10551-016-30527. 
Shields, R., Comegys, C., Lupton, R. and Takei, H. (2013) 'Undergraduate attitudes toward business ethics: a cross-cultural comparison', Journal of Studies in Education, Vol. 3, No. 4, pp.72-80, DOI: 10.5296/jse.v3i4.4179.

Sims, R. and Gegez, A.E. (2004) 'Attitudes towards business ethics: a five nation comparative study’, Journal of Business Ethics, Vol. 50, No. 3, pp.253-265, DOI: 10.1023/B:BUSI. 0000024708.07201.2d.

Smith, J. (2018) 'Efficiency and ethically responsible management', Journal of Business Ethics, Vol. 150, No. 1, pp.603-618, DOI: https://doi.org/10.1007/s10551-016-3175-x.

Suar, D. and Gochhayat, J. (2016) 'Influence of biological sex and gender roles on ethicality', Journal of Business Ethics, Vol. 134, No. 2, pp.199-208, DOI: http://dx.doi.org/10.1007/ s10551-014-2424-0.

The World Bank (2014) GDP Ranking [online] http://data.worldbank.org/data-catalog/GDPranking-table (accessed 14 May 2020).

Thorpe, A. and Roper, S. (2019) 'The ethics of gamification in a marketing context', Journal of Business Ethics, Vol. 155, No. 1, pp.597-609, DOI: 10.1007/s10551-017-3501-y.

Tlaiss, H.A. (2015) 'How Islamic business ethics impact women entrepreneurs: insights from four Arab Middle Eastern countries', Journal of Business Ethics, Vol. 129, No. 4, pp.859-877, DOI: http://dx.doi.org/10.1007/s10551-014-2138-3.

Transparency International (2017) Corruption Perceptions Index 2017 [online] https://www.transparency.org/news/feature/corruption_perceptions_index_2017 (accessed 2 April 2020).

Transparency International (2018) Americas: Weakening Democracy and Rise in Populism Hinder Anti-corruption Efforts - Transparency International [online] https://www.transparency.org/ news/feature/cpi-2018-regional-analysis-americas (accessed 28 May 2020).

van Hoorn, A. (2019) 'Generational shifts in managerial values and the coming of a unified business culture: a cross-national analysis using European social survey data', Journal of Business Ethics, Vol. 155, No. 2, pp.547-566, DOI: http://dx.doi.org/10.1007/s10551-0173488-4.

Vitell, S.J., Rallapalli, K. and Singhapakdi, A. (1993) 'Marketing norms: the influences of personal moral philosophies and organizational ethical cultures', Journal of the Academy of Marketing Science, Vol. 21, pp.331-337, DOI: http://dx.doi.org/10.1007/BF02894525.

Wang, L.C. and Calvano, L. (2015) 'Is business ethics education effective? An analysis of gender, personal ethical perspectives, and moral judgment', Journal of Business Ethics, Vol. 126, No. 4, pp.591-602, DOI: http://dx.doi.org/10.1007/s10551-013-1973-y.

Warren, D.E., Gaspar, J.P. and Laufer, W.S. (2014) 'Is formal ethics training merely cosmetic? A study of ethics training and ethical organizational culture', Business Ethics Quarterly, Vol. 24, No. 1, pp.85-117, DOI: https://doi.org/10.5840/beq2014233.

Weber, J. (2015) 'Investigating and assessing the quality of employee ethics training programs among US-based global organizations', Journal of Business Ethics, Vol. 129, No. 1, pp.27-42, DOI: http://dx.doi.org/10.1007/s10551-014-2128-5. 